\title{
Relationship between the work developed in maximal and submaximal exercise capacity tests and the degree of airflow obstruction in individuals with Chronic Obstructive Pulmonary Disease
}

Relação do trabalho desenvolvido em testes máximo e submáximo de capacidade de exercício com o grau de obstrução ao fluxo aéreo em individuos com Doença Pulmonar Obstrutiva Crônica

Relación de labor desarrollada en tests máximo y submáximo de capacidad de ejercicio con el grado de obstrucción del flujo aéreo en individuos con Enfermedad Pulmonar Obstructiva Crónica

Lucas Araújo de Oliveira', Rafael Mesquita1,2, Igor Lopes de Brito', Viviane de Moraes Laburú', Fabio Pitta', ${ }^{1,3}$ Vanessa Suziane Probst ${ }^{2,3,4}$

\begin{abstract}
I The aim of this study was to investigate the relationship between the work in two exercise capacity tests, a maximum and a submaximal exercise, and the level of airflow obstruction in patients with Chronic Obstructive Pulmonary Disease (COPD). Fifty-three subjects with COPD (29 men, $70 \pm 9$ years old, $65 \pm 14 \mathrm{~kg}$, forced expiratory volume in the first second [FEV] 38[31-54]\% predicted) had their lung function assessed by spirometry, and maximal and submaximal exercise capacity were evaluated by the Incremental Shuttle Walking test (ISWT) and the 6-Minute Walk Test (6MWT), respectively. The work in the tests was calculated by multiplying the covered distance and the individual's body weight (W). To evaluate the contribution of weight on the developed work, subjects were separated into two groups: higher weight ( $n=32)$, and lower weight $(n=21)$. FEV 1 correlated with the distance on the ISWT and with the ISWT*W $(r=0.43$ and $r=0.49$, respectively; $p<0.05$ for both). Moreover, the distance on the ISWT correlated with the ISWT*W ( $r=0.88, p<0.0001)$. Regarding the 6MWT, it was observed that $F E V_{1}$ had a weak correlation with the covered distance $(r=0.29, p=0.03)$ and a moderate one with the $6 \mathrm{MWT}{ }^{*} \mathrm{~W}(r=0.51, p<0.0001)$. Moreover, the distance
\end{abstract}

covered in the 6MWT was moderately correlated with the 6MWT*W ( $r=0.47, p=0.0004)$. The higher weight group showed worse performance only in the 6MWT compared to the lower weight group $(407 \pm 85$ versus $469 \pm 64$ meters, respectively; $\mathrm{p}=0.004$ ). The work on the used exercise tests was similarly related to the level of airflow obstruction. The submaximal test, however, appears to have its performance more influenced by the individuals' body weight.

Keywords I Pulmonary Disease, Chronic Obstructive; Exercise Tolerance; Airway Obstruction.

RESUMO I Objetivou-se investigar a relação do trabalho desenvolvido em dois testes de capacidade de exercício, um máximo e outro submáximo, com o grau de obstrução ao fluxo aéreo em indivíduos com Doença Pulmonar Obstrutiva Crônica (DPOC). 53 indivíduos com DPOC (29 homens, $70 \pm 9$ anos, $65 \pm 14 \mathrm{~kg}$, volume expiratório forçado no primeiro segundo [VEF, 38[31-54]\% previsto) tiveram avaliadas sua função pulmonar, por meio de espirometria, e capacidade de exercício máxima, pelo Incremental Shuttle Walking Test (ISWT), e submáxima, pelo teste de caminhada

Study conducted at the Universidade Estadual de Londrina (UEL) and at Universidade Norte do Paraná (UNOPAR) - Londrina (PR), Brazil. 'Research Laboratory of Pulmonary Physical Therapy (LFIP) at UEL - Londrina (PR), Brazil.

${ }^{2}$ Research Center of Health Sciences (CPCS) at UNOPAR - Londrina (PR), Brazil.

${ }^{3}$ Physical Therapy Department at UEL - Londrina (PR), Brazil.

${ }^{4}$ Physical Therapy course at UNOPAR - Londrina (PR), Brazil. 
de seis minutos (TC6min). O trabalho desenvolvido nos testes foi calculado pelo produto da distância percorrida com o peso corporal do indivíduo (P). Para avaliar a contribuição do peso no desempenho dos testes, os indivíduos foram separados em dois grupos: maior peso ( $n=32$ ), e menor peso ( $n=21$ ). Observou-se correlação do $V_{E F}$ com a distância percorrida no ISWT e com o ISWT*P $(r=0,43$ e r=0,49, respectivamente; $\mathrm{p}<0,05$ para ambas). Além disso, a distância percorrida no ISWT correlacionou-se com o ISWT*P ( $r=0,88$ p<0,0001). Em relação ao TC6min, observou-se que o VEF apresentou correlação fraca com a distância percorrida $(r=0,29 ; p=0,03)$ e moderada com o TC6min*P ( $r=0,51 ; p<0,0001)$. Além disso, a distância percorrida no TC6min correlacionou-se moderadamente com o TC6min*P ( $r=0,47 ; p=0,0004)$. O grupo maior peso apresentou pior desempenho somente no TC6min comparado ao menor peso (407 \pm 85 versus 469 \pm 64 metros, respectivamente; $p=0,004)$ O trabalho desenvolvido nos testes utilizados relacionou-se com o grau de obstrução ao fluxo aéreo de forma semelhante nos dois testes. O teste submáximo, contudo, teve seu desempenho mais influenciado pelo peso corporal dos indivíduos.

Descritores I Doença Pulmonar Obstrutiva Crônica; Tolerância ao Exercício; Obstrução das Vias Respiratórias

RESUMEN I Este estudio tuvo como objetivo investigar la relación de labor desarrollada en dos tests de capacidad de ejercicio, un máximo y otro submáximo, con el grado de obstrucción del flujo aéreo en individuos con Enfermedad Pulmonar Obstructiva Crónica
(EPOC). LOS 53 individuos con EPOC (29 hombres, 70 $\pm 9 A$ ños, $65 \pm 14 \mathrm{~kg}$, volumen espiratorio forzado en el primer segundo [VEF1] 38 [31-54]\% previsto) tuvieron evaluadas su función pulmonar, a través de espirometría, y capacidad máxima de ejercicio en por el Incremental Shuttle Walking Test (ISWT), y submáxima, por el test de caminata de seis minutos (TC6min). El trabajo desarrollado en los tests fue calculado por el producto de la distancia recorrida con el peso corporal del individuo (P). Para evaluar la contribución del peso en el rendimiento de los tests, los individuos fueron separados en dos grupos : de alto peso $(n=32)$ y bajo peso $(n=21)$. Se observó una correlación del VEF1 con la distancia recorrida en el ISWT y con el ISWT*P ( $r=0,43$ y $r=0,49$, respectivamente; $\mathrm{P}<0,05$ para ambos). Además, la distancia recorrida en ISWT se correlacionó con el ISWT*P ( $r=0,88 ; P<0,0001)$. En cuanto al TC6min, se observó que el VEF1 presentó una correlación débil con la distancia recorrida $(r=0,29 ; \mathrm{P}=0,03)$ y moderada a TC6min*P $(r=0,51 ; \mathrm{P}<0,0001)$. Aparte, la distancia recorrida en la TC6min se correlacionó moderadamente con el TC6min*P ( $r=0,47 ; \mathrm{P}=0,0004)$. El grupo de alto peso mostró peor desempeño solamente en el TC6min en comparación con el de bajo peso (407 85 vs. 46964 metros, respectivamente; $\mathrm{P}=0,004)$. El trabajo en los tests utilizados se relacionó con el grado de obstrucción del flujo de aire de manera similar en ambos los tests. El test submáximo, sin embargo, tuvo su rendimiento más influenciado por el peso corporal de los individuos.

Palabras clave I Enfermedad Pulmonar Obstructiva Crónica;

Tolerancia al Ejercicio; Obstrucción Respiratoria..

\section{INTRODUCTION}

Chronic Obstructive Pulmonary Disease (COPD) is characterized by limited airflow, usually progressive and associated with an abnormal inflammatory response of the lungs to the inhaling of toxic particles and/or gases, especially the smoke from cigarretes ${ }^{1}$. Data from the World Health Organization (WHO) indicate that, in 2030, COPD can be the third major cause of death in the world ${ }^{2}$.

Even though COPD affects primarily the lungs, it also has significant systemic effects ${ }^{1}$. Individuals with COPD present relevant decrease in exercise capacity ${ }^{3}$, which happens especially due to ventilatory limitation, abnormalities in gas exchanges, cardiovascular limitation, and respiratory and peripheral muscle dysfunction ${ }^{4}$. The assessment of exercise capacity in individuals with COPD is clinically important, since it allows to measure the severity of the disease ${ }^{5}$, the response to pharmacological and non-pharmacological interventions ${ }^{6,7}$, and even preoperative risk $^{8}$.
Several authors have found weak or no correlation between measures of pulmonary function and covered distance in exercise capacity tests among patients with $\mathrm{COPD}^{9-11}$. Some authors, however, defend that the covered distance in these tests may not be the best outcome to be investigated, and that its product times body weight may have more clinical significance ${ }^{11,12}$. This new outcome has been described as the performance in tests, and it has been used to prescribe the intensity of training in pulmonary rehabilitation programs and to estimate the maximal load in incremental tests ${ }^{13}$.

A few authors investigated the relationship between level of airflow obstruction with the work in exercise capacity tests, and none of them seems to have assessed and compared this relationship between maximal and submaximal tests. While Carter et al..$^{14}$ and Chuang et al. ${ }^{12}$ found correlation between $\mathrm{FEV}_{1}$ and the work in the 6MWT, Teixeira et al. ${ }^{11}$ did not find any correlation. With regard to the Incremental Shuttle Walking Test (field test with incremental aspect), there are no studies that correlated the work in this test with the level of airflow obstruction. 
Therefore, the objective of this study was to investigate the relationship between the work in two exercise capacity tests, a maximal and a submaximal one, with the level of airflow obstruction in individuals with COPD.

\section{METHODOLOGY}

\section{Study design and subjects}

Individuals were recruited in the initial assessment to participate in pulmonary rehabilitation programs. The study was approved by the Ethics Committee, and individuals responded to the informed consent form.

Inclusion criteria were: diagnosis of COPD according to the criteria from the Global Initiative for Chronic Obstructive Lung Disease (GOLD) ${ }^{1}$ absence of exacerbations/respiratory infections for at least three months before the beginning of the study; absence of severe and/or impairing comorbidities, which might interfere in the performance of evaluations and; not having followed any exercise program in the past year. Individuals were excluded in case they did not demonstrate physical and/or cognitive conditions to perform the tests, or in case they gave up participating in the study for any reason.

\section{Procedures}

- Pulmonary function: Simple spirometry was conducted (SpiroBank G, MIR, Italy). The technique was in accordance with international standardization $^{15}$. Measures were obtained after the use of bronchodilator medications (400 mcg of salbuta$\mathrm{mol}$ ), and individuals were classified according to GOLD ${ }^{1}$. Reference values for the Brazilian population were used ${ }^{16}$.

- Maximal exercise capacity: The Incremental Shuttle Walking Test (ISWT) ${ }^{17}$ was used, in its modified ver$\operatorname{sion}^{18}$, to assess the maximal exercise capacity. Reference values were the ones described by Probst et al. ${ }^{19}$.

- Submaximal exercise capacity: It was assessed by the 6 Minute Walking Test (6MWT), conducted according to the guidelines of the American Thoracic Society (ATS) ${ }^{19}$. The reference values of Troosters et $a l .{ }^{20}$ were used.
The exercise capacity tests were used on different days, and each of them was repeated twice, with minimum interval of thirty minutes between them. The largest covered distance was considered for analysis. The work in each test was calculated by the product of the distance times the individual's body weight (distance in kilometers $\mathrm{x}$ weight in kilograms) ${ }^{12}$. This formula comes from the calculation of work in a horizontal surface on a treadmill: K.m.V $\mathrm{T} \cdot \cos \theta^{12}$, in which " $\mathrm{K}$ " is the performance coefficient, " $\mathrm{m}$ " is body weight, "V" is velocity, and " $\mathrm{T}$ " is walking time. Inclination is null and " $\mathrm{K}$ " and " $\mathrm{T}$ " are constant. Therefore, the formula changes into velocity $(\mathrm{V})$ - which may be considered as a performance measure and replaced by distance - multiplied by weight $(\mathrm{m})^{12}$.

In order to assess the contribution of body weight on the performance during tests, individuals were separated in 2 groups: higher weight and lower weight (above or below, respectively, the mean body weight of the total sample).

\section{Statistical analysis}

Sampling calculation was based on the study by Carter et $a .^{14}$, who found a correlation coefficient between $\mathrm{FEV}_{1}$ and performance in 6MWT of 0.52 . By using the software BioEstat ${ }^{\circledR} 3.0$ (Belém, Brazil), with $85 \%$ power and 0.01 alpha, added by $20 \%$ of loss, 53 subjects would be necessary to detect statistically significant correlation.

The Shapiro-Wilk test was used to verify data distribution. For the comparison between groups, the non-paired Student $t$-test — or the One-Way ANOVA (post hoc Tukey) - , and the Mann-Whitney test were used - or Kruskal Wallis (post hoc Dunn). For correlations, the Pearson or Spearman correlation coefficient was used. The adopted significance level was $\mathrm{p}<0,05$, and the used software was GraphPad Prism 5 (GraphPad Software Inc., La Jolla, California, USA).

\section{RESULTS}

The characteristics of the 53 patients are in Table 1 . In the comparison between groups, there was difference only in variables of pulmonary function, as expected. The absolute value of covered distance, in the percentage of the predicted value, and the performance in the 
ISWT in the total sample were of $382 \pm 145 \mathrm{~m}, 60 \pm 21 \%$ of the predicted value and $23.2[15.8-29.5] \mathrm{km} \cdot \mathrm{kg}$, respectively. The values for the same outcomes in the $6 \mathrm{MWT}$ were $445 \pm 79 \mathrm{~m}, 75 \pm 13 \%$ of the predicted value and $28.1[24.3-33.5] \mathrm{km} \cdot \mathrm{kg}$, respectively.

There was correlation between FEV1 and covered distance $(\mathrm{r}=0.43 ; \mathrm{p}=0.001)$ and performance $(r=0.49 ; p=0.0002)$ in the ISWT (Figure 1$)$. In the

Table 1. General characteristics of individuals included in this study

\begin{tabular}{|c|c|c|c|c|}
\hline Characteristic & $\begin{array}{c}\text { Total } \\
\text { sample }\end{array}$ & GOLD II & GOLD III & GOLD IV \\
\hline$n(M / W)$ & $53(29 / 24)$ & $18(8 / 10)$ & $26(15 / 11)$ & $9(6 / 3)$ \\
\hline Age (years) & $70 \pm 9$ & $64 \pm 9$ & $69 \pm 9$ & $66 \pm 7$ \\
\hline Weight (kg) & $66 \pm 14$ & 67 [57-80] & 61 [57-73] & 55 [46-76] \\
\hline Height (m) & $1,61 \pm 0.08$ & $1.59 \pm 0.09$ & $1.62 \pm 0.08$ & $1,61 \pm 0,08$ \\
\hline $\mathrm{BMI}\left(\mathrm{kg} / \mathrm{m}^{2}\right)$ & $26 \pm 6$ & 27 [22-31] & 24 [21-29] & 20 [18-30] \\
\hline $\mathrm{FEV}_{1}(\%$ prev) & 38 [31-54] & $60[53-66]$ & $37[34-42]^{*}$ & $26[22-27]^{* .+}$ \\
\hline FVC (\% prev) & $66 \pm 14$ & 76 [69-83] & $60[55-70]^{*}$ & $62[41-74]^{*}$ \\
\hline FEV/FVC (\%) & $64 \pm 16$ & $78 \pm 9$ & $61 \pm 12^{*}$ & $45 \pm 12^{*, t}$ \\
\hline
\end{tabular}

Data expressed in absolute frequency, mean \pm standard deviation or median linterquartile interval]; M: men; W: women; BMI: Body Mass Index; FEV: Forced Expiratory Volume in the first second; FVC: Forced Vital Capacity; GOLD: Global Initiative for Chronic Obstructive Lung Disease ${ }^{*} \mathrm{p}<0.05$ versus $\mathrm{GOLD} \|$; ${ }^{\dagger} \mathrm{p}<0.05$ versus GOLD III

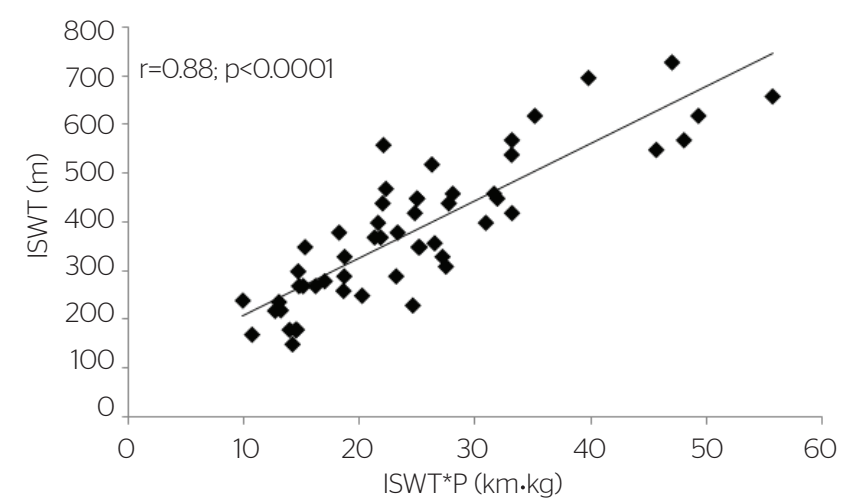

ISWT: Incremental Shuttle Walking Test

Figure 1. Correlation between covered distance and maximal work developed in the Incremental Shuttle Walking Test

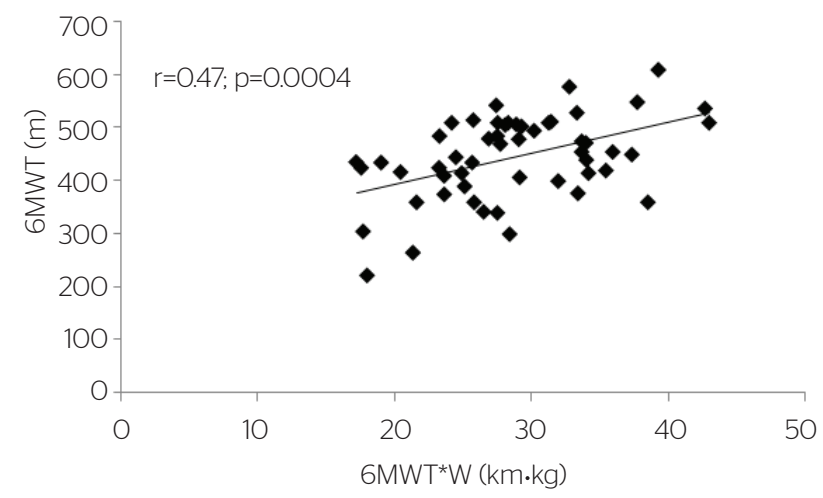

6MWT: six minutes walking test

Figure 2. Correlation between covered distance and maximal work performed in the 6 Minute Walking Test analysis of ISWT*P between groups classified by GOLD, it was observed that the group GOLD II (28.7[23.0-41.3] $\mathrm{km} \cdot \mathrm{kg}$ ) presented more work than groups GOLD III and GOLD IV (21.5[14.7-27.3] $\mathrm{km} \cdot \mathrm{kg}$ and $15.3[13.8-21.7] \mathrm{km} \cdot \mathrm{kg}$, respectively; $\mathrm{p}<0,05)$. The same happened when compared to the covered distance in ISWT $(\mathrm{p}<0.05)$.

In the same analyses for the 6MWT, $\mathrm{FEV}_{1}$ was positively and weakly correlated with the covered distance in the test $(\mathrm{r}=0.29 ; \mathrm{p}=0.03)$, and positively and moderately correlated with the $6 \mathrm{MWT}^{*} \mathrm{P}$ $(r=0.51 ; p<0.0001)$. A moderate correlation was also found between the covered distance in the 6MWT and the $6 \mathrm{MWT}^{*} \mathrm{P}$ (Figure 2). There was no difference in the comparison between the covered distance in groups (GOLD II: $475 \pm 63 \mathrm{~m}$ versus GOLD III: $437 \pm 87 \mathrm{~m}$ versus GOLD IV: $404 \pm 63 \mathrm{~m}, \mathrm{p}>0.05$ ). However, there were differences in the comparison of the $6 \mathrm{MWT}^{*} \mathrm{P}$, since group GOLD II presented higher value than GOLD IV $(31.5 \pm 6.3 \mathrm{~km} \cdot \mathrm{kg}$ versus $23.7 \pm 4.6 \mathrm{~km} \cdot \mathrm{kg}$, respectively; $\mathrm{p}<0.05)$.

There was no statistical difference in the comparison between covered distance in the ISWT among higher weight $(n=21)$ and lower weight $(n=32)$ groups (i.e., above or below sampling mean, respectively). However, in the 6MWT, the higher weight group covered a shorter distance (Figure 3). It was also observed that there was no statistical difference in the comparison of FEV1 between groups (predicted lower weight: $37[31-52] \%$ versus predicted higher weight: $42[31-60] \% ; \mathrm{p}=0.27)$.

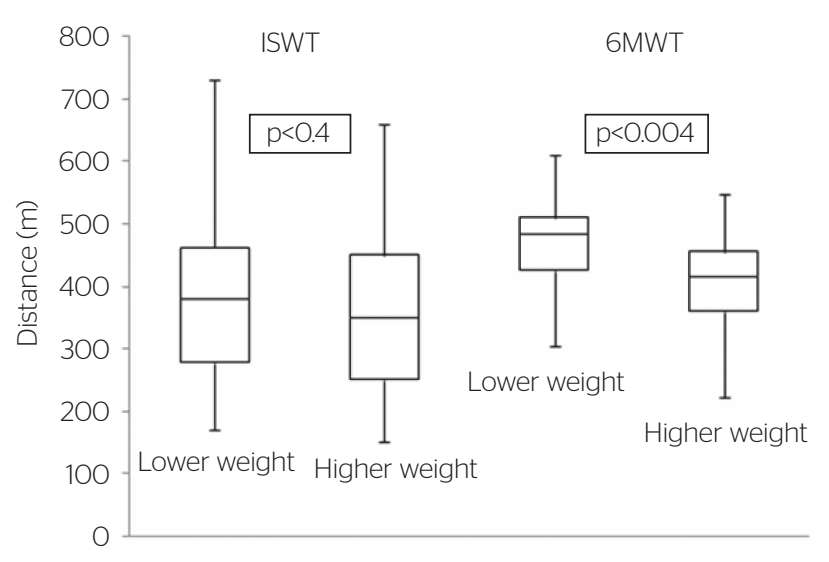

ISWT: Incremental Shuttle Walking Test; 6MWT: six minutes walking test

Figure 3. Comparison between covered distance and higher and lower weight groups in the Incremental Shuttle Walking Test and the 6 Minute Walking Test 


\section{DISCUSSION}

In this study, it was observed that the work performed in maximal and submaximal exercise capacity tests was similarly correlated with the level of airflow obstruction in individuals with COPD. When the relationship between this last variable and the distance covered in tests was analyzed, however, a lower value was observed in the submaximal test. Besides, a weaker correlation was noticed between distance and the work performed in this test. Finally, it was possible to observe that heavier individuals presented with worse submaximal exercise capacity, but not maximal, in relation to those with lower weight.

Several authors investigated the relationship between pulmonary function and distance covered in the 6MWT and in the ISWT ${ }^{9,10}$, however, only a few investigated the relationship with the work performed in these tests. Pitta et al. ${ }^{10}$ did not find any significant correlation between distance covered in the 6MWT and $\mathrm{FEV}_{1}$. Fink et al. ${ }^{9}$ also demonstrated that airflow obstruction is not correlated with exercise capacity in patients with COPD. Other authors even found statistically significant correlations, however, weak ones ${ }^{21-23}$. In this study, $\mathrm{FEV}_{1}$ was correlated with the distance covered in both tests, however, a stronger correlation, even if modest, was verified with the ISWT.

According to Chuang et al. ${ }^{12}$, work is defined as the necessary energy to transport the weight of the body, through specific distance and in a certain period of time. In this study, the work performed in the 6MWT was assessed, and a 0.36 correlation coefficient was found with $\mathrm{FEV}_{1}(P=0.06)$. Likewise, Carter et al. ${ }^{14}$ demonstrated the correlation of pulmonary function variables, like $\mathrm{FEV}_{1}$, with the work performed in the 6MWT. Results in this study, as well as the ones in the analyses by Chuang et $a l^{12}$ and Carter et $a l^{14}$, showed higher correlation between FEV1 and the work performed in the $6 \mathrm{MWT}$ than with the covered distance. Besides, both authors found that walking presented more sensitivity and specificity to predict the exercise capacity in patients with COPD ${ }^{24}$. Differently, Teixeira et al. ${ }^{11}$ did not find a significant correlation between the level of airflow obstruction and the $6 \mathrm{MWT}^{*} \mathrm{P}$, as well as in relation to the covered distance in this test. There are no studies correlating the work performed in the ISWT with pulmonary function variables. In this study, unlike the $6 \mathrm{MWT}$, similar correlation coefficient values were found between $\mathrm{FEV}_{1}$ and the distance and the work performed in ISWT.
It is worth to mention that heavier individuals with COPD presented worse submaximal exercise capacity than lighter individuals; however, there was no difference in the comparison of maximal exercise capacity. Recently, it has been demonstrated that higher body weight (i.e., overweight and obesity) provides better mechanical advantage concerning hyperinsufflation ${ }^{25,26}$. However, this finding does not reflect on more exercise capacity. It is believed that due to differences in test protocols, the performance in the $6 \mathrm{MWT}$ is more prone to changes in heavier individuals than the performance in ISWT, because during the 6MWT people can decrease and adapt velocity to their conditions when feeling difficulties. This is not true for the ISWT, since the individual has no choice but to go according to a standardized velocity to complete the test.

It is known that the 6MWT can also work as a maximal test. According to Troosters et al. ${ }^{27}$, the oxygen consumption $\left(\mathrm{VO}_{2}\right)$ reached and maintained in the 6MWT can be equivalent to the peak $\mathrm{VO} 2$ reached during the incremental test on the bicycle. However, by analyzing the test design, we observed it is a submaximal test. By considering the weight of the patient to find the real work required to conclude the test, we come closer to the person's daily reality. On the other hand, when the objective is to assess the maximal exercise capacity of a patient, tests with standardized protocols, such as ISWT, are necessary.

In spite of all efforts to perform this study, some limitations have occurred. No individual classified as GOLD I was included in the study, which might reduce the external validity of findings; however, it is known that most of these individuals are asymptomatic, and that is why they do not seek medical care, which makes diagnosis more difficult and, consequently, also the participation in studies. In order to assess exercise capacity, the gold standard test (i.e., cardiopulmonary exercise testing ${ }^{28}$ ) was not used due to the difficulty to access laboratories with specific devices. However, in ISWT, the test used to measure the maximal exercise capacity has been proven to be valid in relation to the gold standard ${ }^{4}$.

\section{CONCLUSION}

By means of this study, it is possible to conclude that the work performed in exercise capacity tests is correlated with the level of airflow obstruction similarly 
between maximal and submaximal tests in individuals with COPD. The performance in submaximal tests, however seems to be more influenced by the body weight of individuals than the performance in the maximal test. However, further studies are necessary to prove this finding.

\section{REFERENCES}

1. Vestbo J, Hurd SS, Agusti AG, Jones PW, Vogelmeier C, Anzueto A, et al. Global strategy for the diagnosis, management, and prevention of chronic obstructive pulmonary disease: GOLD executive summary. Am J Respir Crit Care Med. 2013:187(4):347-65.

2. World Health Organization. Burden of COPD [acesso julho de 2012]. Disponivel em: http://www.who.int/respiratory/copd/burden/en/index.html

3. Hernandes NA, Teixeira Dde C, Probst VS, Brunetto AF, Ramos EM, Pitta F. Profile of the level of physical activity in the daily lives of patients with COPD in Brazil. J Bras Pneumol. 2009;35(10):949-56.

4. Singh S, Harrison S, Houchen L, Wagg K. Exercise assessment and training in pulmonary rehabilitation for patients with COPD. Eur J Phys Rehabil Med. 2011;47(3):483-97.

5. Celli BR, Cote CG, Marin JM, Casanova C, Montes de Oca M, Mendez RA, et al. The body-mass index, airflow obstruction, dyspnea, and exercise capacity index in chronic obstructive pulmonary disease. $\mathrm{N}$ Engl J Med. 2004;350(10):1005-12.

6. Cazzola M, MacNee W, Martinez FJ, Rabe KF, Franciosi LG, Barnes PJ, et al. Outcomes for COPD pharmacological trials: from lung function to biomarkers. Eur Respir J. 2008;31(2):416-69.

7. Nici L, Donner C, Wouters E, Zuwallack R, Ambrosino N, Bourbeau J, et al. American Thoracic Society/European Respiratory Society statement on pulmonary rehabilitation. Am J Respir Crit Care Med. 2006:173(12):1390-413

8. Orens JB, Estenne M, Arcasoy S, Conte JV, Corris P, Egan $\mathrm{JJ}$, et al. International guidelines for the selection of lung transplant candidates: 2006 update--a consensus report from the Pulmonary Scientific Council of the International Society for Heart and Lung Transplantation. J Heart Lung Transplant. 2006:25(7):745-55.

9. Fink G, Moshe S, Goshen J, Klainman E, Lebzelter J, Spitzer S, et al. Functional evaluation in patients with chronic obstructive pulmonary disease: pulmonary function test versus cardiopulmonary exercise test. J Occup Environ Med. 2002;44(1):54-8.

10. Pitta F, Takaki MY, Oliveira NH, Sant'anna TJ, Fontana AD, Kovelis D, et al. Relationship between pulmonary function and physical activity in daily life in patients with COPD. Respir Med. 2008:102(8):1203-7.

11. Teixeira PJ, Costa CC, Berton DC, Versa G, Bertoletti O, Canterle DB. Six-minute walk work is not correlated to the degree of airflow obstruction in patients with Chronic Obstructive Pulmonary Disease (COPD). Rev Port Pneumol. 2006:12(3):241-54.
12. Chuang ML, Lin IF, Wasserman $\mathrm{K}$. The body weight-walking distance product as related to lung function, anaerobic threshold and peak VO2 in COPD patients. Respir Med. 2001;95(7):618-26.

13. Cavalheri V, Hernandes NA, Camillo CA, Probst VS, Ramos D, Pitta F. Estimation of maximal work rate based on the 6-minute walk test and fat-free mass in chronic obstructive pulmonary disease. Arch Phys Med Rehabil. 2010;91(10):1626-8.

14. Carter R, Holiday DB, Nwasuruba C, Stocks J, Grothues C, Tiep B. 6-minute walk work for assessment of functional capacity in patients with COPD. Chest. 2003;123(5):1408-15.

15. Miller MR, Hankinson J, Brusasco V, Burgos F, Casaburi R, Coates A, et al. Standardisation of spirometry. Eur Respir J. 2005;26(2):319-38.

16. Pereira CA, Sato T, Rodrigues SC. New reference values for forced spirometry in white adults in Brazil. J Bras Pneumol. 2007:33(4):397-406

17. Singh SJ, Morgan MD, Scott S, Walters D, Hardman AE. Development of a shuttle walking test of disability in patients with chronic airways obstruction. Thorax. 1992:47(12):1019-24.

18. Probst VS, Hernandes NA, Teixeira DC, Felcar JM, Mesquita RB, Goncalves CG, et al. Reference values for the incremental shuttle walking test. Respir Med. 2012;106(2):243-8.

19. ATS Committee on Proficiency Standards for Clinical Pulmonary Function Laboratories. ATS statement: guidelines for the six-minute walk test. Am J Respir Crit Care Med. 2002;166(1):111-7.

20. Troosters T, Gosselink R, Decramer M. Six minute walking distance in healthy elderly subjects. Eur Respir J. 1999;14(2):270-4.

21. Singh S. Walking for the assessment of patients with chronic obstructive pulmonary disease. Eur Respir Mon. 2007:40:148-64.

22. McGavin CR, Artvinli M, Naoe H, McHardy GJ. Dyspnoea, disability, and distance walked: comparison of estimates of exercise performance in respiratory disease. Br Med J. 1978;2(6132):241-3.

23. Mak VH, Bugler JR, Roberts CM, Spiro SG. Effect of arterial oxygen desaturation on six minute walk distance, perceived effort, and perceived breathlessness in patients with airflow limitation. Thorax. 1993:48(1):33-8.

24. Figueiredo PHS, Costa DO, Afeitos TD, Reis WJO. Comparação entre o trabalho desenvolvido e a distância percorrida no teste de caminhada de seis minutos para avaliação da capacidade funcional de pneumopatas crônicos. ASSOBRAFIR Ciência. 2011:2(2):29-36

25. Ora J, Laveneziana P, Ofir D, Deesomchok A, Webb KA, O'Donnell DE. Combined effects of obesity and chronic obstructive pulmonary disease on dyspnea and exercise tolerance. Am J Respir Crit Care Med. 2009;180(10):964-71.

26. O'Donnell DE, Deesomchok A, Lam YM, Guenette JA, Amornputtisathaporn N, Forkert L, et al. Effects of BMI on static lung volumes in patients with airway obstruction. Chest. 2011;14O(2):461-8.

27. Troosters T, Vilaro J, Rabinovich R, Casas A, Barbera JA, RodriguezRoisin R, et al. Physiological responses to the 6-min walk test in patients with chronic obstructive pulmonary disease. Eur Respir J. 2002:20(3):564-9.

28. Palange P, Ward SA, Carlsen KH, Casaburi R, Gallagher CG, Gosselink $\mathrm{R}$, et al. Recommendations on the use of exercise testing in clinical practice. Eur Respir J. 2007;29(1):185-209. 